\title{
Isolation, screening, characterization of proteolytic bacteria and production of protease with its potential applications
}

\author{
Aneela Sharif*, Zahida Nasreen and Sehrish Kalsoom \\ Department of Zoology, University of Mianwali, Mianwali-Pakistan \\ *Corresponding author's email: aneelasharif111@gmail.com \\ Citation \\ Aneela Sharif, Zahida Nasreen and Sehrish Kalsoom. Isolation, screening, characterization of proteolytic bacteria \\ and production of protease with its potential applications. Pure and Applied Biology. Vol. 9, Issue 4, pp2250-2271. \\ http://dx.doi.org/10.19045/bspab.2020.90240
}

Received: 09/03/2020

Revised: $12 / 06 / 2020$

Accepted: 16/06/2020

Online First: 07/07/2020

\section{Abstract}

The purpose of this study was production of protease enzyme by isolated bacteria and evaluation of their potential for various industrial applications. Two strains AN16 and AN13 exhibiting maximum proteolytic activity were used for further studies. The activity of crude enzymes was completely inhibited by phenyl-methyl-sulphobnyl fluoride (PMSF) and ethylene diamine tetraacetic acid (EDTA) had no such negative effect on activity. Enzymes were relatively stable in presence of surface active agents such as Triton X-100, Tween-80, Tween-20 and oxidizing agent $\mathrm{H}_{2} \mathrm{O}_{2}$. The enzymes exhibited maximum activity within $\mathrm{pH}$ range of 7-9. The optimum temperature was recorded to be $37^{\circ} \mathrm{C}$. The relative activity of isolate AN13 protease in presence of metal ions $\mathrm{Ca} 2+, \mathrm{Fe} 2+, \mathrm{Mn} 2+, \mathrm{Mg} 2+, \mathrm{Zn} 2+, \mathrm{Co} 2+, \mathrm{Hg} 2+, \mathrm{Na}+$ was as follow: 107\%, 99\%, $156 \%, 100 \%, 105 \%, 97 \%, 90 \%, 104 \%$ and $102 \%, 101 \%, 145 \%, 80 \%, 98 \%, 90 \%, 98 \%, 96 \%$ for AN16 protease, respectively. The degradation percentage of chicken feathers by crude protease was recorded to be $55.50 \%$ for AN16 followed by AN13 (39.79\%). Study of dehairing activity of protease resulted in complete removal of hairs from hide. De-staining studies showed excellent proteinaceous stain removal efficiency. Antibacterial and antifungal activity of synthesized Silver nanoparticles (AgNPs) used against E. coli $(25 \mathrm{~mm})$, Salmonella typhus $(18 \mathrm{~mm})$ and fungal strain Malassezia $(17 \mathrm{~mm})$ were also recorded. Removal of gelatin from waste x-ray films by enzyme extract showed a weight loss of about 6\% (AN16) and 5\% (AN13). Different low cost media were also tested to support the growth of these proteolytic bacteria exhibiting positive results.

Keywords: AgNP; Dehairing; Detergents additives; Feather degradation; Protease; Silver Recovery

\section{Introduction}

In recent years, there is tremendous rise in the usage of biological catalyst enzymes as industrial catalytic agents. Protease (synonymous as peptidase or proteinase) constitutes one of the largest category of enzymes, which are being used in different industrial sectors [1]. Proteases are enzyme capable of catalyzing hydrolytic reactions in which protein molecules are degraded to peptides and amino acids $[2,3]$.

Protease comprises $60 \%$ of enzyme sales globally. Protease has wide applications in different industries such as laundry detergent additives, for synthesis of peptides, food processing, animal feedstuff production, 
animal hide processing, in pharmaceutical industry, production of amino acids, as cleaning agents of contact lens, sewage treatment etc. $[4,5]$.

Proteases are produced by different microbes such as bacteria, yeasts, actinomycetes molds, and are also produced by different plants and animals [6]. Microorganisms are an attractive source of protease, due to the distinct advantages they offer over plant and animal protease [7].

Microbial protease offer several advantages therefore proteases of microbial origin are given preference then those produced by plants and animals $[8,9]$.

Large varieties of proteases are produced by microorganisms that are either intracellular or extracellular. Extracellular proteases are important for microbial cell because these are able to hydrolyze proteins in cell-free settings. Because of this property, extracellular proteases are valued in different industrial applications where they assist in protein degradation and thus are commercially important [10].

Globally, millions of tons of feathers are produced as a waste by-product by poultry sector annually [11] which contains about $90 \%$ keratin that offers high degree of recalcitrance [12].

Degradation of feather keratin by Bacterial strains producing keratinases is an alternate way to increase the nutritive worth of waste feathers and to avoid environmental pollution. There is increasing attentiveness toward proteases of microbial origin in different commercially important areas of biological sciences such as environment related studies, biomedicine and biotechnology [13].

Keratinase produced by bacteria which are a type of microbial proteases are of great interest due to their effectiveness against unsolvable keratinous waste. There has been extensive research to find out feather keratin hydrolysis potential of protease enzymes that is a by-product of poultry industry being produced in large quantities [14].

It was stated $35 \%$ of the total enzymes produced by various microbes are utilized in detergent industry [15].

Alkaline proteases with keratin hydrolytic action also offer an efficient alternate for treatment of animal hide. Alkaline proteases are also used for recycling of waste x-ray films for recovery of silver. Alkaline proteases are being used for managing effluents from different food based industries and household wastes [16].

Alkaline proteases have high stability even in the existence of different metal ions, denaturing agents, surfactants, oxidants and detergents. Along with these features oxidant and $\mathrm{pH}$ stability of a protease are also most prominent features for their application in detergents and bleaches to improve the washing efficiency. High thermo-stability of alkaline proteases appears to facilitate washing. The use of proteases in detergents could be a possible solution for the problem of removing proteinaceous stains from fabrics [17].

Proteases that have been explored so far are not enough to meet current high industrial demands. Therefore, continuous efforts are being put forward by researchers to find a proteases having novel characteristics of industrial interest from different bacterial strains [18].

Nanotechnology encompassing production and usage of nanoparticles is a rising field having substantial potential for applications in large number of industrial sectors [19]. Silver nanoparticles (AgNPs) are widely acknowledged now-a-days due to their potential for application in many fields such as pharmaceutical industry, biomolecular detection and also can be used widely for their antimicrobial activities [20].

Gelatin is a protein that is present in animal collagen tissues that usually contain high proportion of glycine, proline and 4- 
hydroxyproline amino acid residue. X-ray films are coated with emulsion layers made up of silver and gelatin, so there is possibility to degrade this gelatin coating by protease and to release and recover silver [21]. Silver is an important metal from industrial point of view and is being applied in different sectors such as $\mathrm{x}$-rays and photographic films, silverwares and electronic devices. Recovery of silver from used X-ray films is desirable in order to conserve this valuable metal, being important also from environmental view point [22]. Silver is preferred for $x$ rays and photographic films due to its high quality and light-sensitive properties for creating a photographic image. Burning the X-ray films for silver recovery can create environmental problems as well as health issues. On contrary, enzymes from microorganisms break the gelatin layer embedded with silver in films generating pollution free stripping [23].

Different types of agricultural left over materials such as sugarcane waste, wheat bran, rice bran, potato peel, green gram husk, oil cakes etc. are valuable for supporting growth and production purpose of different enzymes such as cellulase, insulinase, lipase, protease and so on. The agricultural waste by-products can be utilized as substrates for production of enzymes and is advantageous because these are inexpensive, their readily availability and their non-toxicity [24].

Therefore, this study focuses on isolation and screening of potential bacterial strains capable of producing proteases enzyme, utilization of agro-based waste substrates for enzyme production and usage of protease enzyme in various industrial applications. In this research work, soil samples were obtained from various locations of Mianwali District of Punjab, Pakistan for screening of proteolytic bacteria. More over extraction of proteases and their industrially valued applications are assessed.

\section{Materials and methods Sample collection}

Poultry farms and alkaline soil were selected for collection of soil samples. These samples were collected by using sterile spatula in plastic bags and were carried to microbiology laboratory by maintaining aseptic conditions. For future use, these samples were stored in laboratory.

\section{Isolation of Bacteria}

The microorganisms were isolated by serial dilution and spread plate technique on the Casein Agar Media (CAM) containing casein $2 \%$, peptone $0.5 \%$ and agar $1.5 \%$ [25]. In this method, $1.0 \mathrm{~g}$ soil sample was added to $100 \mathrm{ml}$ of distilled water for making a suspension of sample and mixed it well for 15 min. Suitable dilutions of the sample suspension were prepared and $0.1 \mathrm{ml}$ was drawn from each dilution, spread onto the plates of CAM, using sterile glass spreader and incubation was done for 24 hours at $37^{\circ} \mathrm{C}$ for observation of bacterial growth [26]. The clear halo areas of casein hydrolysis were an indication of protease secretion [27]. Then, the protease producers were repeatedly sub cultured on Nutrient Agar Media (NAM) and $\mathrm{CAM}$ for pure culturing of bacterial isolates and were preserved on CAM slants at $4^{\circ} \mathrm{C}$. Isolated strains were named as $\mathrm{AN} 1, \mathrm{AN} 2$, AN3, AN16.

\section{Low cost media screening}

Different agro-based waste materials (rice bran M1, wheat bran M2 [28], orange peel M3, green gram husk M4 [28] banana peel M5 and potato peel M6 [29] were collected from local markets, processed and grinded to obtain suitable particle size. These were then labeled and stored till further use. Cotton oil cakes MO1, Mustard oil cakes MO2 and MO3 (Cotton oil cakes +Mustard oil cakes) were also tested to check their ability of supporting the growth of proteolytic bacterial strains. All of the above mentioned different substrates were tested for growth of proteolytic bacteria. These substrates were 
also used in different combinations in order to check which combination supports maximum growth.

\section{Preparation of low cost substrate media}

Different agro-industrial waste materials, viz. orange peel, green gram husk, rice bran, wheat bran, potato peel, banana peel, cotton oil cakes and mustard oil cakes were obtained and dried using sunlight. These completely dried waste materials were then grinded in a mixer grinder and stored for further use [30]. These agro-based substrates were then screened for the production of protease with little modifications [31]. $4 \mathrm{~g}$ of each of the above mentioned substrate and along with agar were added in $100 \mathrm{ml}$ of distilled water in $250 \mathrm{ml}$ Erlenmeyer flasks. The cotton plugged flasks were autoclaved for 15 mints at $121^{\circ} \mathrm{C}$ and then were allowed to cool. The contents of the flasks were then poured into petri plates and allowed to solidify completely. All strains were then streaked onto the plates and incubated for 24 hours at $37^{\circ} \mathrm{C}$.

All the strains were studied to determine colonial characteristics. Colonial characteristics of all 16 isolated proteolytic strains were noted down. Characteristics of all strains were determined on CAM and also on Low cost media plates and were noted down.

\section{Determination of proteolytic activity}

The Proteolytic activity of all isolated strains was studied by using skim milk agar medium. The milk agar media was prepared according to [32] with little modification. This media was then autoclaved and poured in petriplates (20ml/plate). After complete solidification of the media in plates, strains were streaked onto the surface of media (Fig. 1) and on separate milk agar plates wells of 5 $\mathrm{mm}$ diameter (4 wells per plate) were cut under sterile conditions. These wells were then inoculated with $10 \mu \mathrm{L}$ of nutrient broth culture media having 24-hour growth of selected strains. The plates were subjected to incubation at $37{ }^{\circ} \mathrm{C}$ for 24 hours. Protease production was examined by zone of clearance of opaque milk protein. The diameter of the halo or clear zone formed around the well was measured in order to quantify protease enzyme activity [33]. The high yielding protease strains were assessed by measuring the zone of hydrolysis on skimmed milk agar.

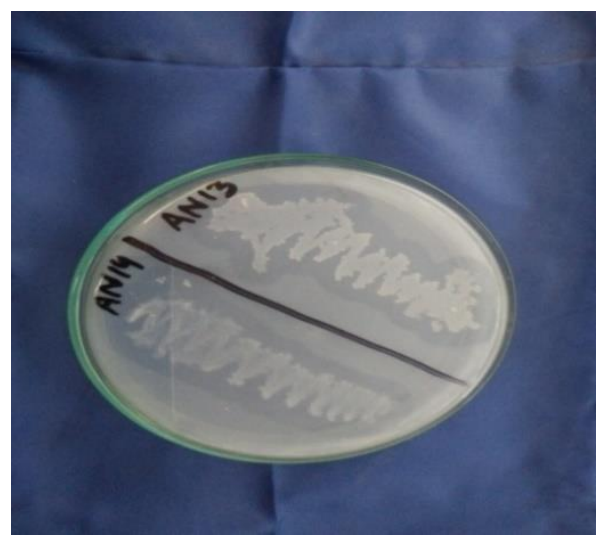

Figure 1. Proteolytic activity of isolated bacteria on skim milk agar media. Proteolytic activity was confirmed by appearance of clear zones around streaked strains

Production of crude protease enzyme extract

The inoculum from pure culture of each isolated proteolytic strain was inoculated into
$100 \mathrm{~mL}$ of alkaline protease broth $(0.5 \%$ glucose, $0.75 \%$ peptone, $0.25 \%$ yeast extract, $0.1 \% \quad \mathrm{~K} 2 \mathrm{HPO} 4, \quad 0.1 \% \quad \mathrm{MgSO} 4, \quad 1.0 \%$ $\mathrm{Na} 2 \mathrm{CO} 3,1.0 \% \mathrm{NaCl})$, pH adjusted to 9.0 and 
incubation was done at $37^{\circ} \mathrm{C}$ [34]. The fermented alkaline protease broth was then subjected to centrifugation at $10,000 \mathrm{rpm}$ for 10 mins. The obtained cell -free supernatant served as crude enzyme extract [35].

\section{Proteases assay}

The protease assay was carried out to measure protease activity as described by [27]. The total volume of reaction mixture was $600 \mu \mathrm{L}$ and its components include $0.5 \%$ azocasein in $50 \mathrm{mM}$ of Tris- $\mathrm{HCl}$ buffer and suitably diluted crude enzyme extract. The incubation of reaction mixture was carried out for a period of 1 hour at $37^{\circ} \mathrm{C}$ and then 0.5 $\mathrm{mL}$ of $10 \%$ trichloroacetic acid (TCA) was added to stop reaction. The un-reacted azocasein precipitate were separated by centrifugation, $1000 \mu \mathrm{L}$ of supernatant was obtained and equal volume of $1.0 \mathrm{M} \mathrm{NaOH}$ was mixed. Spectrophotometer was used to read Absorbance at $440 \mathrm{~nm}$. One unit of protease activity was defined as the amount of enzyme producing $1 \mu \mathrm{g}$ of tyrosine in $1 \mathrm{~min}$ under assay conditions. All protease assays were done in triplicate.

\section{Characterization of protease}

Surface active agents (surfactants) and enzymes inhibitors effect on activity of protease

The effects on enzymes activity under different surfactants as, Tween 20, 80, Triton $\mathrm{X}-100$ ( $0.2 \%$ and $0.4 \%$ final concentration), oxidizing agents such as $\mathrm{H}_{2} \mathrm{O}_{2}$ and enzymes inhibitors including, phenyl-methylsulphobnyl fluoride (PMSF) and ethylene diamine tetra-acetic acid (EDTA) were evaluated by incubation of enzymes for 10 min with each chemical at room temperature. The activity in the absence of inhibitors and surfactants (control) were referred 100\% relative activity. The residual activities were studied and compared to controls.

\section{Effects of metal ions on enzyme activity} $\mathrm{CaCl} 2, \mathrm{MgSO} 4, \mathrm{ZnSO} 4, \mathrm{FeSO} 4, \mathrm{CoCl} 2$, $\mathrm{HgCl} 2, \mathrm{NaCl}$ and $\mathrm{MnSO} 4$ were added to reaction mixture at $1 \mathrm{mM}$ concentration to study effect of metal ions on enzyme activity. Relative activity of enzyme were recorded at room temperature. The enzymes activity without metal ions under similar conditions was expressed as $100 \%$.

Determination of thermostability of protease enzyme

The crude enzymes activity within a temperature range of $37^{\circ} \mathrm{C}$ to $50^{\circ} \mathrm{C}$ were assayed to determine effect of temperature on enzyme activities. The enzymes were preincubated for one hour in $40 \mathrm{mM}$ sodium phosphate buffer to measure thermo stability of enzymes.

\section{Effect of $\mathbf{p H}$ on enzyme activity}

The crude enzymes activity was assayed was at $\mathrm{pH}$ values within range of 6 to 12 in sodium phosphate buffer $(40 \mathrm{mM})$. The enzymes were preincubated for 1 hour at $37^{\circ} \mathrm{C}$ to measure activity under assay conditions.

\section{Applications of bacterial protease enzyme extract}

\section{Inoculum for feather degradation studies}

The growth medium for feather degradation studies was prepared [36]. 50ml of alkaline protease broth was prepared as described above, sterilized at $121^{\circ} \mathrm{C}$ for $15 \mathrm{mins}$ and inoculated with the isolate AN13 and AN1 strains. The incubation of broth was done for $24 \mathrm{hrs}$. at $37^{\circ} \mathrm{C}$ and used as inoculum.

\section{Degradation of chicken feather}

Degradation of chicken feather was carried out as described by [36]. The feathers were cut into small pieces of about $1 \mathrm{~cm}$ long and added to the fermentation media in flasks. The flasks were then incubated at $37^{\circ} \mathrm{C}$ for 4 days. The resulting degradation of keratinous waste was determined in percentage $(\%)$ of weight loss after 4 days of incubation and absorbance of reaction mixture was determined after 4 and 8 days of incubation Evaluation of degree of degradation (DD) Degree of degradation was measured as per method stated by [36]. Feathers were weighed before and after degradation. The residual feathers after completion of 4 days 
period of incubation were removed from reaction mixture and were washed and completely dried to evaluate degree of degradation by using the following formula: $\mathrm{DD}(\%)=(\mathrm{TF}-\mathrm{RF}) \times 100 / \mathrm{TF}$

Where, TF -Total Feather

\section{And}

RF -Residual Feather.

\section{De-Hairing Activity of protease enzyme}

Broth for protease enzyme production was prepared, inoculated with strains AN13 and AN16 and incubated for a period of 3 days [37]. The supernatant of alkaline protease broth was centrifugated at 10,000 rpm for 15 mins and it was used as crude enzyme for dehairing purpose.

Dehairing studies were done by adding the crude enzyme extract on detergent washed cow hide by dip method, to check for its ability to remove hairs. In this method, washed hide pieces were immersed in $10 \mathrm{ml}$ of crude enzyme extract in petri plates and then incubated at $37^{\circ} \mathrm{C}$ for 14 hours [38].

\section{Proteinaceous stain removal studies}

Detergent additive properties of bacterial proteases enzyme was studied on white cotton cloth pieces $(10 \times 10 \mathrm{~cm})$ blemished with chocolate, and spicy food as per [39].

The following experimental groups were set to study stain removal efficiency of protease enzyme:

1. Flask with distilled water $(100 \mathrm{ml})+$ stained cloth (stained with spicy food and chocolate).

2. Flask with distilled water $(100 \mathrm{ml})+$ stained cloth (stained with spicy food and chocolate $)+1 \mathrm{ml}$ Ariel detergent $(10 \mathrm{mg} / \mathrm{ml})$. 3. Flask with distilled water $(100 \mathrm{ml})+$ stained cloth (stained with spicy food and chocolate $)+1 \mathrm{ml}$ Ariel detergent $(10 \mathrm{mg} / \mathrm{ml})$ $+2 \mathrm{ml}$ of enzyme extract.

All the flasks were then kept in incubator at $60^{\circ} \mathrm{C}$ for 15 minutes to check removal of proteinaceous stains. Untreated stained pieces of cloth were labelled as control.
Synthesis of silver nanoparticles by isolated strains

Isolated bacterial strains AN13 and AN16 were inoculated in $100 \mathrm{ml}$ sterile nutrient broth in Erlenmeyer flask and incubated for $48 \mathrm{~h}$ at $37^{\circ} \mathrm{C}$. Cultures were centrifugated at $10,000 \mathrm{rpm}$ for 15 minutes to obtain supernatant for AgNPs synthesis. The supernatant was then utilized to study AgNPs production by adding it with $\mathrm{AgNO} 3$ solution at $1 \mathrm{mM}$ final concentration [40].

For the synthesis of AgNPs by isolated strains, $5 \mathrm{ml}$ silver nitrate (AgNO3) solution $(1 \mathrm{mM})$ was mixed with $10 \mathrm{ml}$ of the supernatant and another solution without silver nitrate addition was labeled as control. The prepared solutions were then incubated at $30^{\circ} \mathrm{C}$ for a period of $24 \mathrm{hrs}$. All solutions were incubated under dark conditions to avoid any photochemical reactions. After 24 hours, the solution turned into brown from yellow solution. The AgNPs were purified by centrifugation at $10,000 \mathrm{rpm}$ for 15 mins, supernatant and particles were collected for further use [41].

\section{Characterization of nanoparticles}

The color changes from yellow to dark brown color in reaction mixture evidenced the production of AgNPs and this was due to efficient reduction of the $\mathrm{Ag}$ ions by bacteria. The exact mechanism of silver ion's reduction and production of silver nanoparticles is still not clear, but it is believed that enzymes including nitrate reductase are the agents responsible for silver nanoparticles synthesis. The colored solution were further studied to measure the absorbance against distinct wave length for confirmation for AgNPs formation.

Formation of silver nanoparticles can be detected easily with the help of spectroscopy. So reaction mixture absorbance was determined at $400 \mathrm{~nm}$ in order to measures optical density [41]. 


\section{Antibacterial and Antifungal Activity of silver nanoparticles}

Antibacterial activity and antifungal activity of prepared AgNPs were carried out by Well diffusion method against Gram negative bacteria Escherichia coli, Salmonella typhus and Malassezia sp. The bacterial cultures and fungal strains were brought into nutrient broth for antibacterial and antifungal assay. Wells of $5 \mathrm{~mm}$ diameter were cut on MacConkey Agar for E. coli, SalmonellaShigella(SS) agar for Salmonella typhus by sterilized cork borer. Composition of the media used for fungi was: Peptone $2 \%$, Glucose $1 \%$, Yeast extract $0.2 \%$, Ox Bilo $0.8 \%$, Glycerol 1\%, Tween 80 0.5\%, Agar $1.5 \%$. [42]. Then $1 \mathrm{ml}$ of broth cultures were evenly spread on solidified media. $5 \mu \mathrm{l}$ of synthesized AgNPs were transferred into the wells and then incubation of plates was carried out at $37^{\circ} \mathrm{C}$ for 24 hours and the inhibition zones were determined [43].

Clearing of waste X-Ray films and Hydrolysis of gelatin by crude enzyme extract

X-ray films were cleaned by washing with distilled water and wiped with cotton balls soaked with ethanol and were then kept in clean glass Petri plates. The washed films were dried in an oven at $40^{\circ} \mathrm{C}$ for $20 \mathrm{~min}$. Waste x-ray films ( $3 \times 3 \mathrm{~cm}$ pieces) were then subjected to incubation with $10 \mathrm{ml}$ of each culture supernatant of AN13 and AN16 so that the films were completely dipped in the solution at $40^{\circ} \mathrm{C}, \mathrm{pH} 10$ with continuous shaking. There was a gradual increase in turbidity of the reaction mixture (as the hydrolysis continued). Progress of hydrolysis was examined by observing turbidity and determining the absorbance at $400 \mathrm{~nm}$ [44].

\section{Statistical analysis}

All experiments were conducted three times and the results were stated as the mean. Means, standard deviations (SD) and standard error of mean (SEM) were analyzed using MS Excel. Single factor analysis of variance (ANOVA) was carried out for some experimental data while remaining data was evaluated by t-test using MS Excel. Results were regarded statistically significant only when p-value was equal to or less than 0.05 . All the data are presented graphically as mean \pm S.D. of replicates. The error bars in the experiments indicate \pm standard deviation.

\section{Results and discussion}

\section{Isolation of bacteria}

A total of 16 morphologically distinct colonies were isolated by using CAM from the collected poultry form soil samples and alkaline soil samples. 6 isolates from poultry form soil samples and 10 isolates from alkaline soil sample were isolated. All the isolated strains were streaked repeatedly on NAM and CAM for pure culturing. Pure cultured colonies were then preserved on CAM slants, covered with paraffin oil and stored till use at $4^{\circ} \mathrm{C}$.

\section{Screening of proteolytic activity of isolated} strains

All isolates were studied for their proteolytic activity on skim milk agar plates and activity was expressed in $\mathrm{mm}$ diameter of zones of clearance. Protease activity was observed from zone of clearance (Fig. 1) formed around the colony on agar surface and also the diameter of zone of hydrolysis around wells was measured as described in (Table 1). Among 16 isolates, AN16 was identified as the most potential strain; since AN16 showed the maximum proteolytic activity having average halo zone of $34.75 \mathrm{~mm}$ diameter followed by AN13 with clear zone of 31.5 $\mathrm{mm}$ and AN9 with zone diameter of $30.5 \mathrm{~mm}$ and AN11 of $30 \mathrm{~mm}$ (Fig. 2). These AN13 and AN16 strains showing largest zone of clearance were chosen for further studies. The results of the screening studies thus indicated that maximum zone of clearance and thereby maximum protease activity by AN9, AN11, AN13 and AN16 and all the isolated strains are significantly different in their proteolytic activity $(\mathrm{P}<0.05)$. 
Table 1. Average values of Halo Zone on skim milk agar after 24 hours of incubation

\begin{tabular}{|c|c|}
\hline Strains & Diameter of zone of clearance $(\mathbf{m m})$ Means \pm SEM \\
\hline AN1 & $28.25 \pm 2.46$ \\
\hline AN2 & $27.5 \pm 1.44$ \\
\hline AN3 & $22.25 \pm 1.10$ \\
\hline AN4 & $20 \pm 0.81$ \\
\hline AN5 & $18 \pm 1.22$ \\
\hline AN6 & $17.75 \pm 1.31$ \\
\hline AN7 & $22 \pm 0.70$ \\
\hline AN8 & $29.75 \pm 1.93$ \\
\hline AN9 & $30.5 \pm 2.17$ \\
\hline AN10 & $22 \pm 1.77$ \\
\hline AN11 & $30 \pm 1.63$ \\
\hline AN12 & $20.25 \pm 3.09$ \\
\hline AN13 & $31.5 \pm 1.5$ \\
\hline AN14 & $29.5 \pm 3.01$ \\
\hline AN15 & $26 \pm 0.57$ \\
\hline AN16 & $34.75 \pm 0.85$ \\
\hline Control & Nil \\
\hline
\end{tabular}

Values represent means of four replicates \pm S.E.M

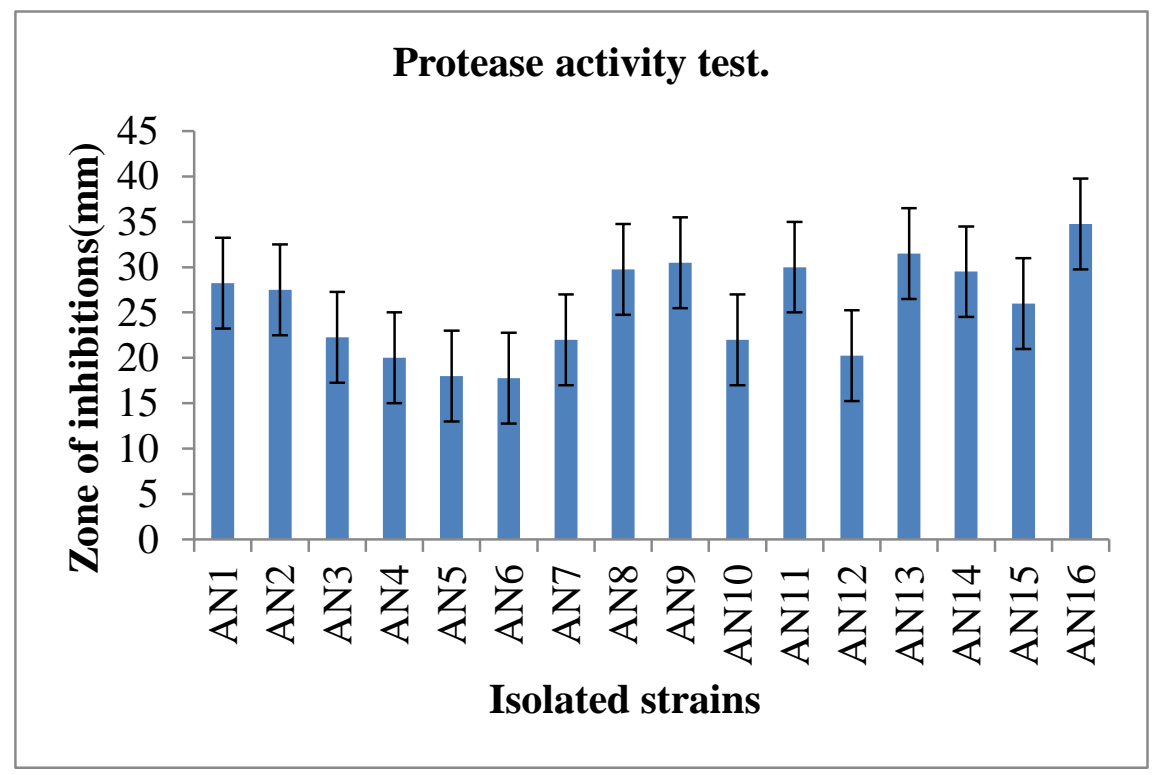

Figure 2. Zones of clearance of skim milk agar media (mean $\pm \mathrm{SD} n=4$ ). All the 16 isolated strains are significantly different from each other in their proteolytic activity $(P<0.0001)$

\section{Low cost substrates screening}

Substrate serves as mean to support growth of bacterial strains. A desirable solid substrate can support good growth and maximum product formation. It has been reported that at industrial level, substrates used for enzyme production for various applications account for $40 \%$ of the total cost; therefore, new formulation of media with cost-effective components is necessary $[45,46]$. Of all the substrate tested for growth, all the 8 substrates which include 
green gram, rice bran, orange peel, banana peel, potato peel and wheat bran, mustard oil cakes and cotton oil cakes ideally supported the growth of proteolytic strains (Table 2). Cattle feed (oil cakes) and green gram husks supported maximum growth hence it was further use to grow the isolated strains instead of using CAM. Morphological characters of colonies on low cost media were noted down.

Table 2. Growth of isolated strains on low cost media

\begin{tabular}{|c|c|c|c|c|c|c|c|c|}
\hline $\begin{array}{c}\text { Isolated } \\
\text { Strains }\end{array}$ & $\begin{array}{c}\text { Green } \\
\text { gram } \\
\text { (M4) }\end{array}$ & $\begin{array}{c}\text { Rice } \\
\text { Bran } \\
\text { (M1) }\end{array}$ & $\begin{array}{c}\text { Orange } \\
\text { Peel } \\
\text { (M3) }\end{array}$ & $\begin{array}{c}\text { Banana } \\
\text { peel } \\
\text { (M5) }\end{array}$ & $\begin{array}{c}\text { Potato } \\
\text { peel } \\
\text { (M6) }\end{array}$ & $\begin{array}{c}\text { Wheat } \\
\text { Bran } \\
\text { (M2) }\end{array}$ & $\begin{array}{c}\text { Mustard } \\
\text { oil cakes } \\
\text { (MO2) }\end{array}$ & $\begin{array}{c}\text { Cotton } \\
\text { oil cakes } \\
\text { (MO1) }\end{array}$ \\
\hline AN1 & ++ & + & + & + & - & + & ++ & + \\
\hline AN2 & + & - & + & + & + & ++ & + & + \\
\hline AN3 & + & + & + & + & + & ++ & + & ++ \\
\hline AN4 & ++ & + & - & + & ++ & + & + & + \\
\hline AN5 & + & + & + & + & + & + & ++ & + \\
\hline AN6 & + & + & - & + & + & + & + & - \\
\hline AN7 & + & + & + & - & + & - & + & + \\
\hline AN8 & ++ & - & + & + & + & + & + & ++ \\
\hline AN9 & - & + & + & - & + & + & ++ & + \\
\hline AN10 & + & + & - & + & + & + & + & + \\
\hline AN11 & + & + & + & + & - & + & + & + \\
\hline AN12 & + & - & + & ++ & + & - & + & + \\
\hline AN13 & ++ & + & + & ++ & + & + & + & ++ \\
\hline AN14 & + & + & + & + & - & - & + & ++ \\
\hline AN15 & - & + & + & - & + & + & ++ & + \\
\hline AN16 & + & + & + & + & + & + & + & ++ \\
\hline
\end{tabular}

$(-)$ represents no significant growth activity; (+) represents significant growth activity; (++) represents highly significant growth activity

\section{Characterization studies}

Effect of surfactants and inhibitors on protease activity

Different chemical compounds effect on activity of crude enzyme of isolated strains AN13 and AN16 showed variations (Table 3). Triton-X-100 increased activity of AN13 crude enzymes at $0.4 \%$ of final concentration, in contrast to Tween-80 negatively affected enzymes activity especially of AN16 crude enzymes. Tween20 had no such negative effect on activity of AN13 crude protease and had slight negative effect on AN16 crude enzymes. The enzymes were relatively stable in presence of EDTA. Proteases activity was inhibited drastically under PSMF.

These results are in contrast to earlier reports where all used inhibitors such as EDTA,
Triton-X-100, Tween-80 negatively affected enzyme activities. Activity of protease was decreased $50 \%$ with EDTA and $43 \%$ with SDS [47].

\section{Metal ions effect on enzyme activity}

The enzyme activity in presence of different metal ions is described in (Table 4). The ion $\mathrm{Ca} 2+$ increased the protease activity thus making enzymes of both strains stable. In this context, the ions $\mathrm{Mg} 2+$ had no inhibitory effect on AN13 crude enzyme but negatively affected AN16 enzymes and Fe2+ had no such negative effect on activity. In contrast to this, Mn2+ remarkably increased enzyme activity (56\%) which may be due to the fact the enzyme uses $\mathrm{Mn} 2+$ as a cofactor.

It has been reported that Bacillus cereus NC77 produced protease was activated in presence of $\mathrm{Zn} 2+, \mathrm{Mg} 2+, \mathrm{Mn} 2+, \mathrm{Ca} 2+$, 
$\mathrm{Na} 2+$ and $\mathrm{Co} 2+$ with $153,134,116,128,125$ and $109 \%$ increment in relative activities respectively [47]. The $145,142,115,119$,
136 , and $133 \%$ of relative activity of protease by addition of $\mathrm{Zn} 2+, \mathrm{Ca} 2+, \mathrm{Cu} 2+, \mathrm{Mn} 2+, \mathrm{Na}+$, and $\mathrm{K}+$ have been reported [48].

Table 3. Effect of some chemical compounds on proteases activity

\begin{tabular}{|c|c|c|c|}
\hline \multirow{2}{*}{ Chemical compounds } & \multirow{2}{*}{$\begin{array}{c}\text { Final } \\
\text { concentration }\end{array}$} & \multicolumn{2}{|c|}{$\begin{array}{c}\text { Residual activity of protease } \\
\text { enzymes (\%) }\end{array}$} \\
\cline { 2 - 4 } & & AN13 & AN16 \\
\hline Control & - & 100 & 100 \\
\hline \multirow{2}{*}{ Phenylmethylsulphobnyl fluoride (PMSF) } & $0.2 \%$ & 15 & 88 \\
\cline { 2 - 4 } & $0.4 \%$ & 6 & 60 \\
\hline \multirow{2}{*}{ Ethylenediaminetetraacetic acid (EDTA) } & $0.2 \%$ & 98 & 95 \\
\cline { 2 - 4 } & $0.4 \%$ & 96 & 90 \\
\hline \multirow{2}{*}{ Triton X-100 } & $0.2 \%$ & 97 & 99 \\
\cline { 2 - 4 } & $0.4 \%$ & 105 & 90 \\
\hline \multirow{2}{*}{ Tween-80 } & $0.2 \%$ & 96 & 85 \\
\cline { 2 - 4 } & $0.4 \%$ & 90 & 80 \\
\hline \multirow{2}{*}{ Tween-20 } & $0.2 \%$ & 99 & 97 \\
\cline { 2 - 4 } & $0.4 \%$ & 97 & 90 \\
\hline \multirow{2}{*}{$\mathrm{Urea}^{*} \mathrm{H}_{2} \mathrm{O}_{2}$} & $0.2 \%$ & 108 & 88 \\
\hline & $0.4 \%$ & 99 & 98 \\
\hline
\end{tabular}

Table 4. Effect on different metal ions on activity of protease

\begin{tabular}{|c|c|c|}
\hline \multirow{2}{*}{ Metal ions } & \multicolumn{2}{|c|}{ Relative activity (\%) } \\
\cline { 2 - 3 } & $\mathbf{A N 1 3}$ & AN16 \\
\hline $\mathrm{Ca} 2+$ & 107 & 102 \\
\hline $\mathrm{Fe} 2+$ & 99 & 101 \\
\hline $\mathrm{Mn} 2+$ & 156 & 145 \\
\hline $\mathrm{Mg} 2+$ & 100 & 80 \\
\hline $\mathrm{Zn} 2+$ & 105 & 98 \\
\hline $\mathrm{Co} 2+$ & 97 & 90 \\
\hline $\mathrm{Hg} 2+$ & 99 & 98 \\
\hline $\mathrm{Na}+$ & 101 & 96 \\
\hline
\end{tabular}

\section{Thermostability of enzyme activity}

The thermostability of crude enzymes of strains AN13 and AN16 were studied and it was found that enzymes were active within the temperature range of $37^{\circ} \mathrm{C}$ to $50^{\circ} \mathrm{C}$ with maximum activity at $37^{\circ} \mathrm{C}$ (Fig. 3) thus making them suitable for their applications in industries. The crude enzymes activity under different temperatures has been reported earlier. The protease produced by strain
SD11 showed activity within range of 30 to $70^{\circ} \mathrm{C}$ and highest activity was recorded at $60 \circ \mathrm{C}$. The relative activity at 50 and $60 \circ \mathrm{C}$ was $97 \%$ and $100 \%$ respectively.

\section{Effect of pH on enzyme activity}

The $\mathrm{pH}$ effect on enzyme activity was studied (Fig. 4) and it was found that enzymes showed maximum activities at 7-9 $\mathrm{pH}$ thus making them desirable for future uses. 
This type of results has already been reported. Bacillus cereus NC77 has been reported to have optimum $\mathrm{pH} 7.0$ to 8.0 for enzyme production [47]. The SD11 Marine
Bacteria protease showed maximum activities at $\mathrm{pH}$ between $8.0-11.0$ and 10.0 was recorded to be optimum $\mathrm{pH}[48]$.
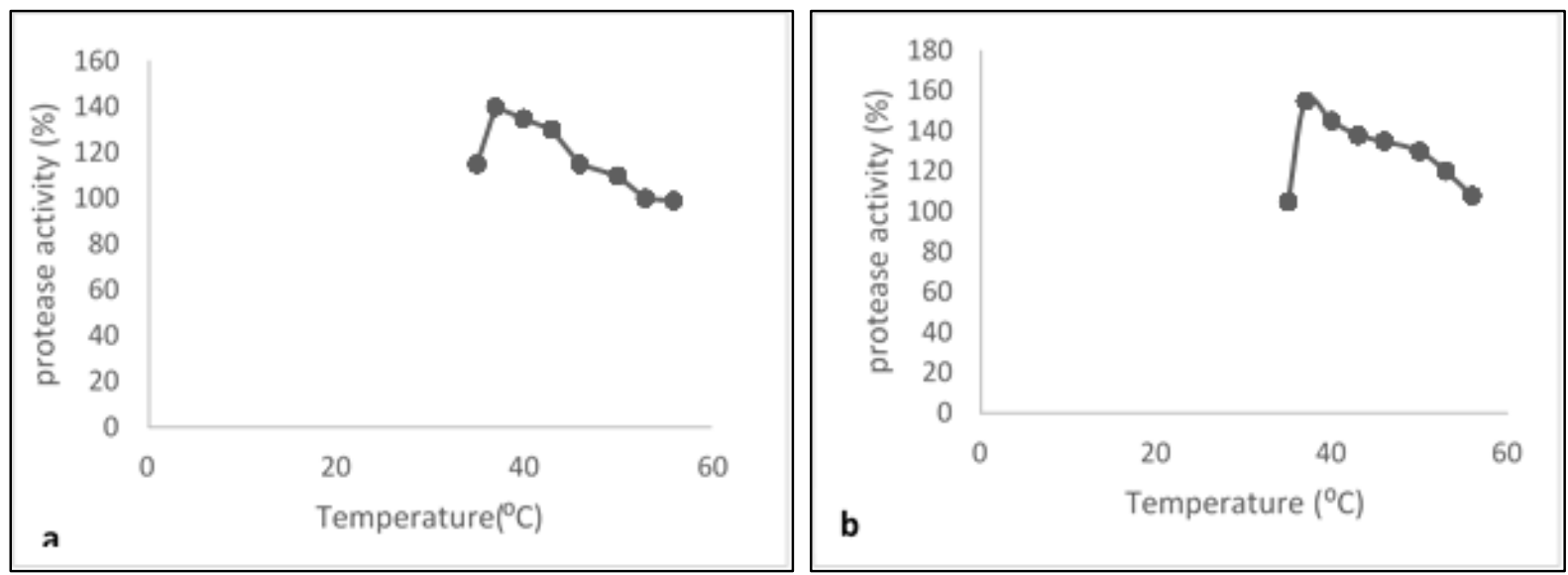

Figure 3. Effect of temperature on crude protease activity of (a) AN13 and (b) AN16
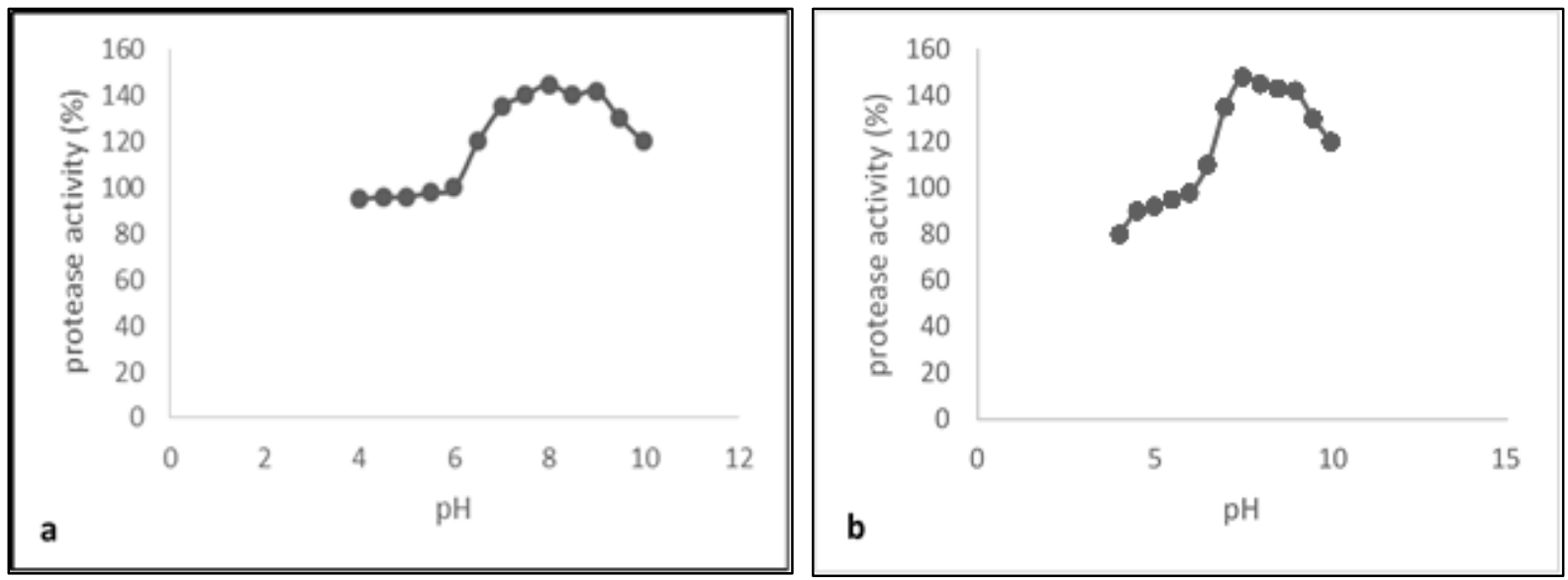

Figure 4. Effect of pH on protease activity of (a) AN13 and (b) AN16

Degradation of Chicken feather and evaluation of degree of degradation (DD)

The crude enzyme extracts from AN13 and AN16 were used for analyzing the degree of chicken feather degradation. After 4 days of incubation, the maximum average degradation capacity was exhibited by AN16 and AN13 was $55.50 \%$ and $39.79 \%$ respectively (Table 5). Optical density was also measured at 400nm after 4 and 8 days (Fig. 5) of incubation by spectrophotometer.
This is the confirmation of earlier reports where maximum feather degradation capacity was exhibited by different bacterial strains as described by [35]. Degradation capability of the crude enzyme extract could be credited to microbial degradation of feather keratin which involves proteolysis and sulfitolysis. All experiments were performed in triplicates. Hydrolysis of keratin of feathers by bacterial protease preparation was also reported by [49]. 
Table 5. Average values of Degree of degradation DD $(\%)=($ TF-RF $) \times 100 /$ TF of chicken feathers after 4 days of incubation

\begin{tabular}{|c|c|c|c|}
\hline Strains & $\begin{array}{l}\text { Initial weight } \\
\text { of feather }(\mathrm{g})\end{array}$ & $\begin{array}{c}\text { Weight of residual feather (g) (After } 4 \text { days). } \\
\text { Means } \pm \text { S.E.M }\end{array}$ & $\begin{array}{c}\text { Degradation } \\
\text { capacity\% (DD) }\end{array}$ \\
\hline AN13 & 1 & $0.6020 \pm 9.4876^{*}$ & $39.79 \%$ \\
\hline AN16 & 1 & $0.4449 \pm 11.4797 *$ & $55.50 \%$ \\
\hline Control & 1 & $1 \pm 0$ & 0 \\
\hline
\end{tabular}

Asterisk $(*)$ represents statistical significance ( $t$-test). $\mathrm{P}$ value was found to be statistically significant $(\mathrm{P}<0.05)$. The $\mathrm{p}$ value indicates the comparison of feather degradation activity of two strains as compared to control. This comparison is found to be statistically significant

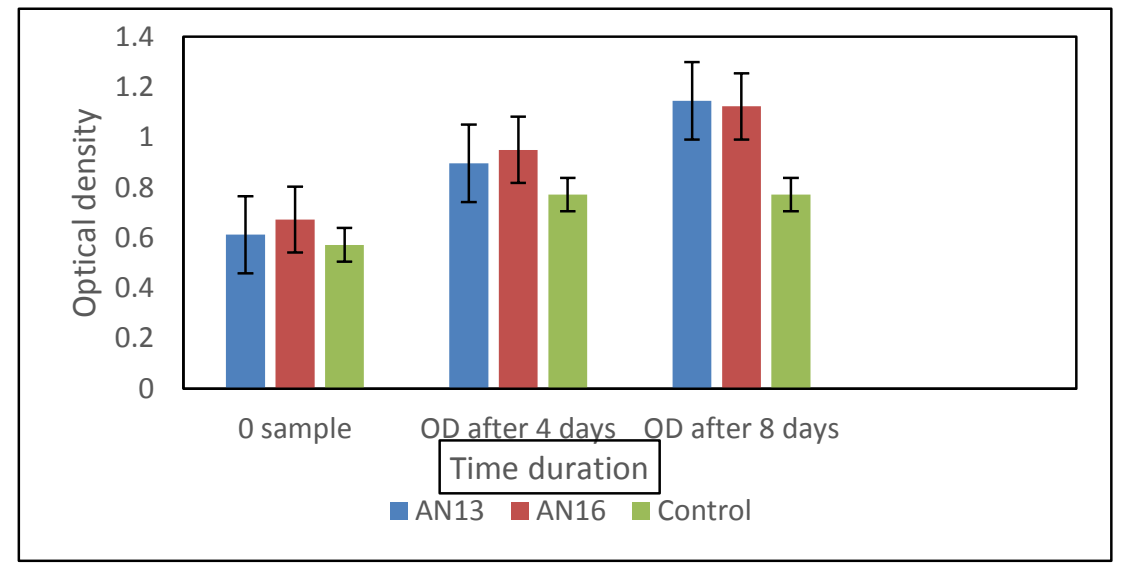

Figure 5. Optical density of zero samples, after 4 and 8 days of incubation (means \pm SD. $n=3$ ). $P$ value was statistically significant $(P<0.05)$

According to [50], feather weight loss after degradation by Bacillus licheniformes was found to be $87.2 \%$ and about $49.4 \%$ weight loss by Bacillus subtilis. Similarly, it was studied that the Keratinase enzyme produced by Streptomyces sp. JRS 18 effectively degraded keratin present in chick feathers, thus helping in poultry waste management [13]. Degradation of chicken feathers by Bacillus sp. has also been stated by [51]. It was studied that keratinase produced by Bacillus sp. possess high feather degradation efficiency [52]. Similarly, [53] found that protease produced by bacterial strain Bacillus amyloliquefaciens has potential to degrade chicken feathers. Bacillus sp. was found to be able to cause $1 \%$ feather degradation within 7 days [54]. Micrococcus sp. and Streptococcus sp. showed keratin degradation activity as evident from decrease in the feathers weight from $0.05 \mathrm{gm}$, to $0.03 \mathrm{gm}[55]$.

\section{De-staining Activity}

To study detergent additive properties of protease enzyme for improvement of washing performance of detergent, destaining studies were carried out. After incubation, cloth pieces were washed with water and air dried. Rinsed cloth pieces were visually examined and it showed that protease enzyme significantly improved removal of stains. The addition of the crude enzyme extract in detergent (Ariel) considerably improved the removal of spicy food and chocolate stains within 15 minutes. The best results were observed when protease and detergent both were used together. The compatibility of bacterial along with detergents has also been reported by [56] where protease retained maximum activity even after treatment with detergent thus proving the constancy of protease in detergents. The protease enzyme produced removed the spicy food and chocolate stains 
with great efficiency within the short time period of 15 minutes which indicates it's prospective to be used as detergent additive in laundry detergent industries. This is in accordance with earlier reported work of [57] on laundry detergent additive application of protease where protease enzyme was used in conjunction with detergent to improve proteinous stain removal from fabrics. The similar observations were also reported by $[58,59,60]$. Protease produced by Bacillus subtilis also showed high potential of removing the dye and blood stains from cloth. Blood stains were removed efficiently by alkaline protease that was used along with detergent within short period of time as compared to when only detergent was used for stain removal [61].The protease obtained from Streptomyces gulbargensis completely removed proteinous stains within 20 min of incubation of cotton pieces of cloths [62]. Protease enzyme produced by Bacillus subtilis was found to be very efficient in removal of blood stain from cloth within 30 min so it can be used as bio-detergent [63]. In the same way, protease was able to retain its $50-76 \%$ of activity at $40^{\circ} \mathrm{C}$ in detergents such as surf excel, Ariel and Ghadi etc. and thus it is compatible to be used with commercial detergents for improving stain removal efficiency [23]. Thus it is proved that protease enzyme can be used in detergents. The B. licheniformis crude protease enzyme showed remarkable blood stain removal
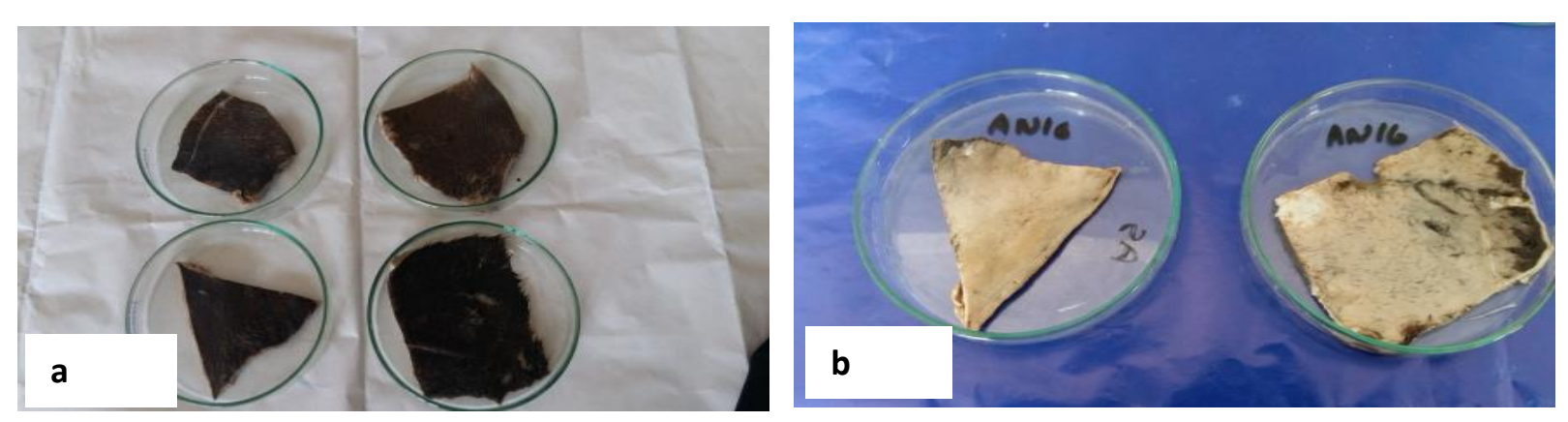

Figure 6. (a) Cow hides before incubation with protease enzyme extract of AN13 and AN16. (b) Cow hides after 24 hrs of incubation with protease enzyme extract of AN13 and AN16 efficiency and compatibility with different commercial detergents [64].

\section{Dehairing of hide}

Protease dehairing activity was carried out by dip method. After 14 hours of incubation, dehairing activity of enzyme obtained from isolated strain AN13 and AN16 was proved to be efficient in dip method. Adequate dehairing activity by dip method was observed. At the end of the incubation, the skin pieces were scraped gently with the fingers to loosen the hair. Complete skin depilation was observed after incubation of the skin with the partial purified enzyme produced by AN13 and AN16 (Fig.6) whereas, the hair on hide remain intact in control. Similar dehairing studies with bacterial protease were reported earlier by [65]. Dehairing of skin by protease produced by Bacillus $s p$. has also been demonstrated in a study by [66]. [66] also reported complete removal of hair from skin by simple scraping with fingers. [67] reported excellent hide dehairing ability of Nocardiopsis dassonvillei NRC2aza.

Keratinase produced by Bacillus thuringiensis strain Bt407 caused swelling of root hairs and subsequent removal of hair from goat hide after 24 hours of incubation, so it can be used as depilatory agent in leather industry [68]. Some other bacterial strains having similar depilatory effect on hides are Bacillus pumilus CBS Alkaline Proteinase [69], Bacillus cereus MCM B-326 [70] and Bacillus safensis LAU 13 [71]. 


\section{Synthesis of silver nanoparticles}

After 24h of incubation, AgNPs production was confirmed by visual examination of Culture supernatant changing in color from light yellow to brown (Fig. 7). Control (without AgNO3) exhibited no evidence of color development in the reaction media when incubated for the same time period and under same conditions.

The AgNO3-treated culture supernatant turned brown in color suggesting synthesis of AgNPs [72]. Thus it supported the fact that color change is indication of AgNPs formation. Nitrate reductase, a NADPHdependent enzyme is responsible for change in color due to silver metal ions reduction and thus is the main agent carrying synthesis of silver nanoparticles [73]. Silver ions underwent bio reduction with the help of reduction of specific enzymes leading to formation of silver metal ion aggregates which in turn form the desired silver nanoparticle $[73,74]$.

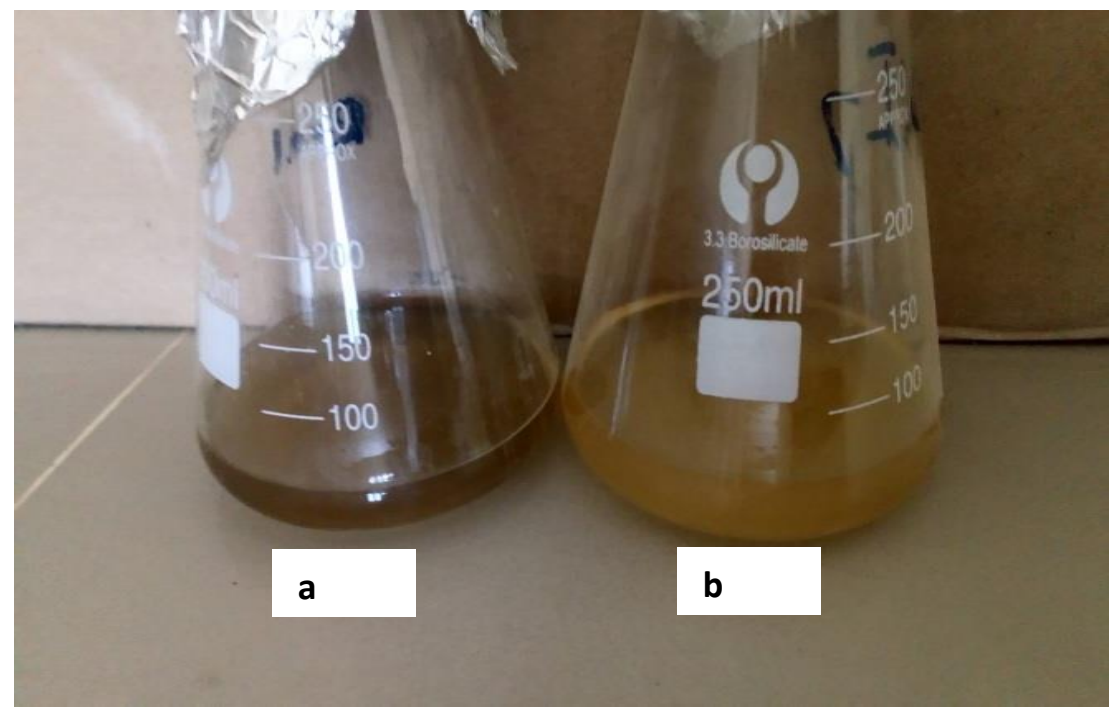

Figure 7. (a) Control solution for synthesis of silver nanoparticles by isolated bacterial strains. (b) Solution after synthesis of silver nanoparticles by isolated bacterial strains. Color changes indicate formation of nanoparticles

\section{UV Spectroscopy}

The confirmation of the AgNPs synthesis was examined by UV spectroscopic studies by drawing out aliquots of colloidal solution (after reaction completion) that were used for UV-spectroscopic observations. The reaction mixture showed absorbance at $400 \mathrm{~nm}$ and thus confirmed the nanoparticles synthesis by using the culture supernatant. The UV absorbance is shown in (Fig. 8). Absorbance was measured after 24 hours of incubation. UV Absorbance of zero samples was also measured. The OD absorption units for AN13 was at 2.213 and for AN16, it was 2.121 after 24 hours of incubation as compared to control with OD absorption units at 1.118 for AN13 and 1.012 for AN16 (Table 6).

The control (without AgNO3) exhibited no signs of absorption at $400 \mathrm{~nm}$. The samples exposed to the silver nitrate solution showed absorbance at around $400 \mathrm{~nm}$. The occurrence of absorbance indicates the accumulation of the AgNPs in the solution. 


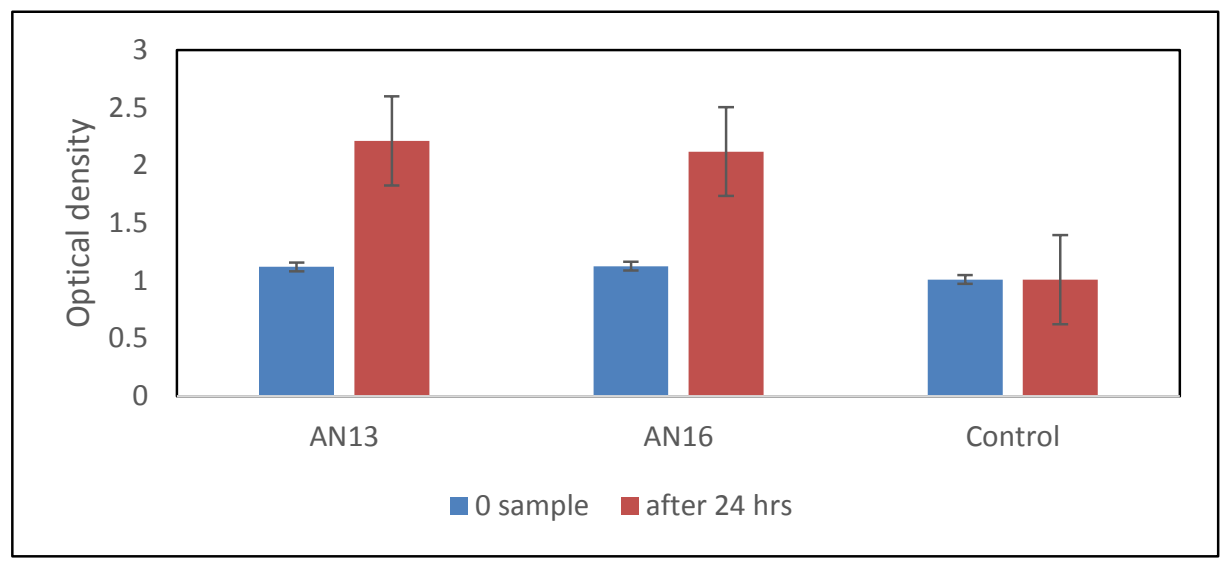

Figure 8. Optical density of zero samples and after 24 hrs of incubation (means \pm S.D., $n=3$ )

Table 6. OD values of silver nanoparticles solution after $24 \mathrm{hrs}$ of incubation

\begin{tabular}{|c|c|c|}
\hline Strains & $\begin{array}{c}\text { Optical Density of zero sample } \\
\text { (Means } \pm \text { S.E.M) }\end{array}$ & $\begin{array}{c}\text { Optical Density after 24 hours } \\
\text { (Means } \pm \text { S.E.M) }\end{array}$ \\
\hline AN13 & $1.121 \pm 0.052^{*}$ & $2.213 \pm 0.085^{* *}$ \\
\hline AN16 & $1.127 \pm 0.052^{*}$ & $2.121 \pm 0.118^{* *}$ \\
\hline Control & $1.011 \pm 0.080$ & $1.011 \pm 0.080$ \\
\hline
\end{tabular}

Values represent means of three replicates \pm S.E.M. The values are significantly different in comparison with corresponding control $* \mathrm{P}<0.001, * * \mathrm{P}<0.0001$

\section{Antibacterial and Antifungal activity of AgNPs solution}

The antimicrobial activities of biologically synthesized AgNPs were tested against an isolated pathogenic gram negative bacteria and a fungal strain Malassezia sp. and results were recorded in (Table 7). The AgNPs showed strong antibacterial activity against Gram-negative bacteria, Escherichia coli and Salmonella typhi. The maximum inhibition zone was observed against Escherichia coli having a halo zone of $25 \mathrm{~mm}$ diameter and maximum halo zone produced against Salmonella typhi by the silver nanoparticles was $18 \mathrm{~mm}$. The inhibition zone against isolated fungal spp. was found to be about $17 \mathrm{~mm}$ in diameter (Fig. 9). No zone of inhibition was observed around the well filled with only $1 \mathrm{mM} \mathrm{AgNO} 3$ (Control) confirming antibacterial activity of biosynthesized silver nanoparticles. This is in confirmation with earlier reports where microbially synthesized AgNPS exhibited high antimicrobial activity. Silver nanoparticles produced by Bacillus sp. and marine bacteria Ocrobactrum anthropi exhibited zone of inhibition measuring $13 \mathrm{~mm}$ and $14 \mathrm{~mm}$ against Salmonella typhi, $17 \mathrm{~mm}$ and $15 \mathrm{~mm}$ against Salmonella paratyphi respectively while both AgNPs exhibited $15 \mathrm{~mm}$ zone of inhibition against Staphylococcus aureus [75]. Antibacterial action of silver nanoparticles synthesized by Streptococcus sp. showed very strong inhibitory effect against $S$. typhi $(40 \mathrm{~mm}$ inhibitory zones) followed by E.coli $(34 \mathrm{~mm}$ zone of inhibition) [76]. Inhibitory effect of AgNPs against E.coli has also been described [77]. Silver nanoparticles are also been reported to be effective against important disease causing bacterial strains such as E.coli, Salmonella typhimurium, Bacillus subtilis and Enterococcus faecalis [78]. The general mechanism behind antibacterial properties of silver nanoparticles is the $\mathrm{Ag}$ ions from nanoparticles that are supposed to get attached with cell wall of bacteria having negative charge and further causing its lyses. 
This in turn leads to denaturation of major proteins thus causing cell death [79]. The nanoparticles synthesis mechanism is considered to be reduction of metal ions, in this case Ag ions into silver nanoparticles by bacterially secreted enzymes such as nitrate reductase [19]. Similar process has been discovered in Bacillus licheniformis where nanoparticles synthesis by silver ions reduction was observed and enzyme responsible for it was found to be nitrate reductase [80]. The syntheses of silver nanoparticles by Bacillus strain and by Bacillus megaterium have also been reported [81]. Antifungal properties of AgNPs have also been reported. It is shown that AgNPs have significant antifungal activity against plant pathogenic fungus Rhizoctonia solani [82]. Likewise, Silver nanoparticles can be effective as antifungal agent against Aspergillus sp. [83].

Table 7. Silver nanoparticles zones of inhibition against E. Coli, Salmonella typhus and a fungus Malassezia spp.

\begin{tabular}{|c|c|c|c|}
\hline \multirow{2}{*}{ Strains } & \multicolumn{3}{|c|}{ Halo zones Diameters (mm) (Means \pm S.E.M) } \\
\cline { 2 - 4 } & E. Coli & Salmonella typhus & Malassezia spp \\
\hline AN13 & $16.5 \pm 3.30^{*}$ & $6.75 \pm 1.43^{*} *$ & $10.5 \pm 0.64^{*}$ \\
\hline AN16 & $11 \pm 1.41^{*}$ & $15.25 \pm 1.37^{* *}$ & $11.75 \pm 2.78^{*}$ \\
\hline Control & $2.12 \pm 0.27$ & $2.02 \pm 0.40$ & $1.62 \pm 0.31$ \\
\hline
\end{tabular}

Values represent means of four replicates \pm S.E.M. Values are significantly different in comparison with control (One way ANOVA). * represents $\mathrm{p}$ value $(\mathrm{P}<0.01) . * *$ represents $\mathrm{p}$ value $(\mathrm{p}<0.001)$

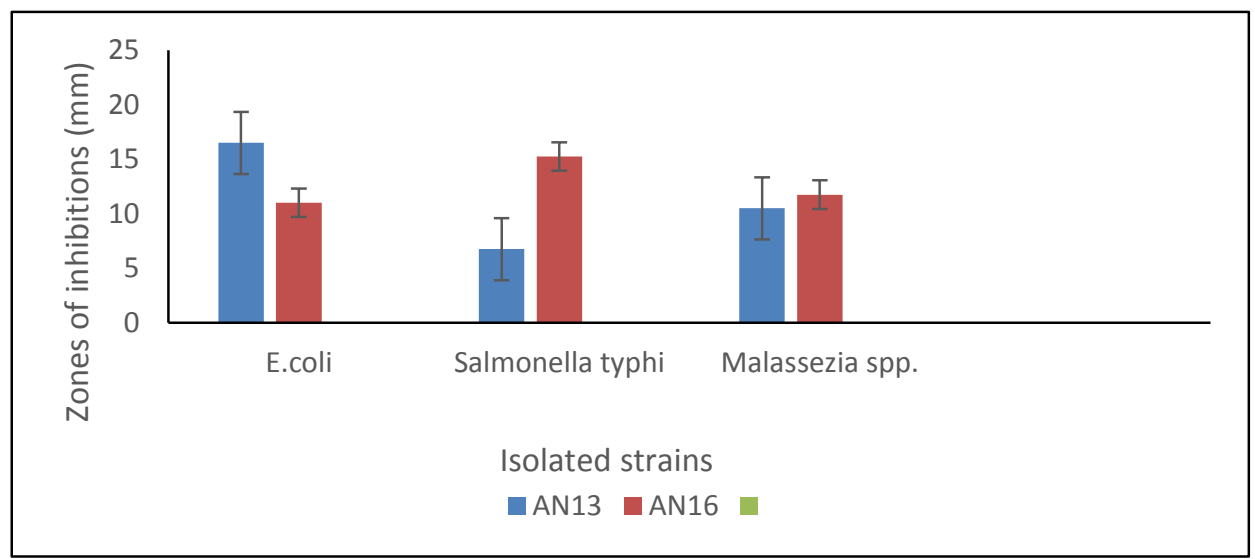

Figure 9. Silver nanoparticles (produced by AN13 and AN16) zone of inhibitions against $E$. coli Salmonella typhus and a fungal specie Malassezia. (Means \pm S.D., $n=4$ )

Gelatin hydrolysis and release of silver from Waste X-ray films

Incubation of waste X-ray films with proteolytic enzymes released gelatin bound with silver into the reaction solution and clean x-ray films were recovered. Protease crude extract of strain AN13 and AN16 were tested for their gelatin removal efficiency from X-ray films. The gelatin degradation capability of isolated strains AN13 and AN16 is shown in (Table 8). The weight loss after treatment was around $5 \%(\mathrm{w} / \mathrm{w})$ for $\mathrm{AN} 13$ and $6 \%$ for AN16.

The bacterial protease enzyme extract worked on the gelatin coating of x-ray film and thus caused release of the bound metallic silver into the solution. The increase in optical density of reaction mixture after 24 hrs. as compared to zero sample solution confirmed the release of silver due to hydrolysis of gelatin (Table 9). The solution was filtered to separate the black silver 
released after hydrolysis by an ordinary filtration methods [40].

This is in confirmation with earlier reports where recovery of silver with degradation of gelation by protease produced by Conidiobolus coronatus and Streptomyces avermectinus was observed [84].

Protease produced by Bacillus cereus strain S8 has high potential to be applied for the silver recovery from waste X-ray films through gelatin coatings [85]. Similarly, protease from Bacillus subtilis was found to be effective for silver recovery [86]. Proteolytic enzymes have also been reported to be involved in treatment of used X-ray film for silver recovery [87]. The Bacillus licheniformis crude protease showed breakdown of gelatin layer from X-ray films making it helpful in recovery of silver [64].

Table 8. Percentage (\%) weight loss of treated X-Ray Film pieces

\begin{tabular}{|c|c|c|c|}
\hline Strains & $\begin{array}{c}\text { Initial weight } \\
\text { (Before) in (g) }\end{array}$ & $\begin{array}{c}\text { Residual weight } \\
\text { (After treatment) } \\
\text { in (g) }\end{array}$ & \% weight loss \\
\hline AN13 & 0.45 & $0.39 \pm 0.57^{*}$ & $5 \%$ \\
\hline AN16 & 0.46 & $0.39 \pm 0.88^{*}$ & $6.3 \%$ \\
\hline Control & 0.45 & $0.44 \pm 0.005$ & Nil \\
\hline
\end{tabular}

Values represent replicate of three means \pm S.E.M. Values are significantly different in comparison with control (One way ANOVA). * represents p value $(\mathrm{P}<0.0001)$

Table 9. Optical density (OD) measured at $400 \mathrm{~nm}$ after 24 hours

\begin{tabular}{|c|c|c|}
\hline Strains & $\begin{array}{c}\text { Optical Density of zero sample } \\
\text { (Means } \pm \text { S.E.M) }\end{array}$ & $\begin{array}{c}\text { Optical Density after 24 hours } \\
\text { (Means } \pm \text { SE.M) }\end{array}$ \\
\hline AN13 & $0.715 \pm 0.002^{*}$ & $0.8853 \pm 0.128^{* *}$ \\
\hline AN16 & $0.751 \pm 0.035^{*}$ & $2.314 \pm 0.217^{* *}$ \\
\hline Control & $0.237 \pm 0.136$ & $0.237 \pm 0.136$ \\
\hline
\end{tabular}

Values are significantly different in comparison with control (One way ANOVA). * represents $\mathrm{p}$ value $(* \mathrm{P}<0.005$, $* * \mathrm{P}<0.0005)$

\section{Conclusion}

The results of this study showed the significance of efficient protease producer strains AN13 and AN16.Thus AN13 and AN16 strain protease may find the applications in different industrial processes and biotechnological fields. Findings of this study supports that naturally available sources can be used for isolation of potent microbes and usage of agricultural by products for supporting growth and production of industrially important enzymes. The present study also revealed that the protease enzyme produced by AN13 and AN16 strain showed positive result in removal of chocolate and spicy food stain from the stained cloth. Therefore, this enzyme found significant application in detergent industry. Protease enzyme produced by these strains has extreme chicken feather degradation activity so it can be employed for poultry feed production and in keratin waste management. This study also proved that protease enzyme of AN13 and AN16 can be used efficiently in leather industry for eco-friendly, efficient and low cost removal of hairs from hides. These strains also have potential to synthesize silver nanoparticles that can be used for their antibacterial and antifungal activity in pharmaceutical industry. They can also be used in silver recovery due to their ability to degrade gelatin in used $\mathrm{x}$-ray films after which silver can be recovered from them. Hence, it is proved that protease enzyme produced by these isolated strains have 
immense potential to be applied in various commercial industries.

\section{Authors' contributions}

Conceived and designed the experiments: $\mathrm{Z}$ Nasreen \& A Sharif, Performed the experiments: A Sharif, Analyzed the data: A Sharif \& Z Nasreen, Contributed materials/ analysis/ tools: S Kalsoom \& Z Nasreen, Wrote the paper: A Sharif.

\section{Acknowledgments}

Authors are thankful to University of Mianwali, Mianwali and District Diagnostic Lab, Mianwali for providing necessary facilities for conducting this research.

\section{References}

1. Jisha VN, Smitha RB, Pradeep SS, Sreedevi S, Unni KN, Sajith, S, Priji P, Josh MS \& Benjamin S (2013). Versatility of microbial proteases. Adv Enzyme Res 1: 39-51.

2. Sharma KM, Kumar R, Vats S \& Gupta A (2014). Production, partial purification and characterization of alkaline protease from Bacillus aryabhattaiK3. Inter $J A d v$ Pharm Biol Chem 3: 290-298.

3. Parpalliwar JP, Patil P, Patiland ID \& Deshannavar UB (2015). Extraction of Silver from waste $x$-ray films using protease enzyme. Inter $J$ Adv Biotech Res (IJBR) 6: 220-226.

4. Rao CS, Sathish T, Ravichandra P \& Prakasham, RS (2009). Characterization of thermo- and detergent stable serine protease from isolated Bacillus circulans and evaluation of eco-friendly applications. Process Biochem 44: $262-$ 268.

5. Mhamdi S, Ktari N, Hajji S, Nasri M, Kamoun AS (2017). Alkaline proteases from a newly isolated Micromonospora chaiyaphumensis S103: Characterization and application as a detergent additive and for chitin extraction from shrimp shell waste. Inter J Biol Macromol 94: 415-422.

6. Banik RM \& Prakash M (2004). Laundry detergent compatibility of the alkaline protease from Bacillus cereus. Microbiol Res 159: 135-140.
7. Ravishankar K, Kumar PS, Jacob B, Saravanan K, Kumar MA \& Jacob A (2012). Optimal conditions for production of extracellular alkaline protease from a newly isolated Bacillus subtilis strain AKRS3. Res Biotech 3: 45-54.

8. Sharma KM, Kumar R, Panwar S \& Kumar A (2017). Microbial alkaline proteases: Optimization of production parameters and their properties. J Genet Eng Biotech 15: 115-126.

9. Choudhury T \& Panday AK (2014). Optimization of environmental and nutritional conditions for the production of protease by Gymnascelladan kaliensis. J Microbiol Biotech Res 4: 19-22.

10. Hamza TA (2017). Bacterial Protease Enzyme: Safe and Good Alternative for Industrial and Commercial Use. Int $J$ Chem Biomol Sci 3: 1-10.

11. Santos RMDB, Firmino AAP, de Sa CM \& Felix CR (1996). Curr Microbiol 33: 64-370.

12. Singh $\mathrm{T} \&$ Kushwaha RKS (2015). Keratinases and microbial degradation of Keratin. Adv Appl Sci Res 6:74-82.

13. Jayalakshmi T, Krishnamoorthy P, kumar GR, Sivamani P \& Lakshmi CGA (2012). Application of pure keratinase on keratinous fibers to identify the keratinolytic activity. J Chem Pharm Res 46: 3229-3233.

14. Lin X, Kelemen DW, Miller ES \& Shih JC (1995). Nucleotide sequence and expression of kerA, the gene encoding a keratinolytic protease of Bacillus licheniformis PWD-1. Appl Environ Microbiol 61: 1469-1474.

15. Ferrero MA, Castro GR, Abate CM, Baigori MD \& Sineriz F (1996). Thermostable alkaline proteases of Bacillus licheniformis MIR 29: Isolation, production and characterization. Appl Microbiol Biotechnol 45(3): 327-332.

16. Kanmani R, Dhivya S, Jayalakshmi S \& Vijayabaskar P (2011). Studies on detergent additives of protease enzyme from an estuarine bacterium Bacillus cereus. Inter Res J Biotech 2: 157-163. 
17. Singh SK, Tripathi VR \& Garg SK (2011). An oxidant, detergent and salt stable alkaline protease from Bacillus cereus SIU1. African J Biotech 10: 12257-12264.

18. Rupali D (2015). Screening and Isolation of Protease Producing Bacteria from Soil Collected from Different Areas of Burhanpur Region (MP) India. Inter $J$ Curr Microbiol Appl Sci, 4: 597-606.

19. Duran N, Marcato DP, Alves LO, De Souza G \& Esposito E (2005). Mechanical aspect of biosynthesis of silver nanoparticles by several Fusarium oxysporum strains. J Nanobiotechnol 3: 815.

20. Lakshmi BKM \& Hemalatha KPJ (2016). Eco Friendly Recovery of Silver from Used X-ray Films by Alkaline Protease of Bacillus cereus Strain S8. Front Environ Microbiol 2: 45-48.

21. Nakiboglu N, Toscali D \& Yasa I (2001). Silver recovery from waste photographic films by an enzymatic method. Turk $j$ chem 25: 349-353.

22. Kumari K, Jandaik S \& Batta S (2015). Recovery of silver from used X-ray films by protease isolated from Bacillus $s p$. ATP-P5 and its immobilization. $J$ pure appl Microbiol 9: 371-375.

23. Choudhary V (2012). Compatibility with commercial detergents and stain removal capability of Aspergillus versicolor Protease. J Acad Indus Res 1: 301-305.

24. Dixit D \& Nigam VK (2014). Microbial Production of Alkaline Proteases Using Agricultural By-Products. Int J Adv Res 2: 407-412.

25. Padmapriya M and Williams BC. (2012). Purification and characterization of neutral protease enzyme from Bacillus Subtilis. $J$ Microbiol Biotech Res 2: 612-618.

26. Jasuja ND, Saxena R, Chandra S \& Joshi SC (2013). Isolation and identification of microorganisms from polyhouse agriculture soil from Rajasthan. African $J$ Microbiol Res 7: 4886-4891.

27. Olajuyigbe FM \& Ajele JO (2005). Production dynamics of extracellular protease from Bacillus species. African $J$ Biotechnol 4: 776-779.

28. Ramakrishna DPN, Reddy NG \& Gopal SVR (2012). Solid State Fermentation for the Production of Alkaline Protease by Bacillus Subtilis Khs-1(Mtcc No-10110) Using Different agro-Industrial Residues. Int J Pharm Pharm Sci 4: 512-517.

29. Kocher GS \& Joshi N (2015). Production And Partial Purification Of Alkaline Protease From Bacillus Circulans Mtcc 7906 Using Potato Peel As Substrate. Indian J Microbiol Res 2:7-13.

30. Kuberan T, Sangaralingam S \& Arasu VT (2010). Isolation and optimization of Protease producing Bacteria from Halophilic soil. J Biosci Res 1: 163-174.

31. Dutta M, Chamendra N, Pai SG, Pramod T \& Siddalingeshwara KG (2014). Isolation and screening of agro-waste substrates for protease production through solid state fermentation. Int $J$ Curr Microbiol Appl Sci 3: 774-781.

32. Sivanandhini T, Subbaiya R, Gopinath M, Angrasan JKVM, Kabilan T \& Selvam MM (2015). An Investigation On Morphological Characterization Actinomycetes Isolated From Marine Sediments. Res J Pharm Biol Chem Sci 6: 12-34.

33. Mazzucotelli CA, Ponce AG, Kotlar CE \& Moreira MR (2013). Isolation and characterization of bacterial strains with a hydrolytic profile with potential use in bioconversion of agro-industrial byproducts and waste. Food Sci Technol (Campinas) 33: 295-303.

34. Verma T \& Baiswar V (2013). Isolation and Characterization of Extracellular Thermoalkaline protease producing Bacillus cereus isolated from tannery effluent. Inter J Eng Sci 2: 23-29.

35. Thazeem B, Beryl GP \& Umesh M (2017). A comparative study on alkaline protease production from Bacillus SPP. and their biodegradative, and de-staining activity. Int J Acad Res Dev 2: 74-79.

36. Masih H \& Singh S (2014). Degradation of Keratinous Waste Products by 
Keratinolytic Bacteria Isolated from soil. Inter J Eng Comput Sci 3: 7588-7595.

37. Uddin ME, Maitra P, Faruquee HM \& Alam MF (2014). Isolation and Characterization of Proteases Enzyme from Locally Isolated Bacillus $s p$. American J Life Sci 2: 338-344.

38. Shivasharana CT \& Naik GR (2012). Ecofriendly applications of thermostable alkaline protease produced from a Bacillus sp. JB-99 under Solid State Fermentation. Inter J Environ Sci 3: 956-960.

39. Adinarayana KP, Ellaiah P \& Prasad DS (2003). Purification and partial characterization of thermostable serine alkaline protease from a newly isolated Bacillus subtilis PE-11. Pharm Sci Technol 4: 56-64.

40. Anju S, Kondari SR \& Sarada J (2014). Bioprocess of silver extraction from used X-ray and MRI films. Acta Biol Ind 3: 561568.

41. Singh I \& Kushwaha RKS (2015). Keratinases and microbial degradation of Keratin. Adv Appl Sci Res 6:74-82.

42. Kaneko T, Makimura K, Abe M, Shiota R, Nakamura Y, Kano R, Hasegawa A, Sugita T, Shibuya S, Watanabe S, Yamaguchi H, Abe S \& Okamura N (2007). Revised Culture-Based System for Identification of Malassezia Species J Clin Microbiol 45: 3737-3742.

43. Paul D \& Sinha SN.(2014). Extracellular Synthesis of Silver Nanoparticles using Pseudomonas aeruginosa KUPSB12 and its Antibacterial Activity. Jordon J Biol Sci 7: 245-250.

44. Shankar S, More SV \& laxman RS (2010). Recovery of silver from waste $\mathrm{x}$-Ray film by alkaline Protease from Conidiobolus coronatus. Kathmandu Univ J Sci Eng Technol 6: 60-69.

45. Hinman RL (1994). The changing face of the fermentation industry. Chemtech 24: 45-48.

46. Joo HS, Kumar CG, Park GC, Kim KT, Paik SR \& Chang CS (2002). Optimization of the production of an extracellular alkaline protease from
Bacillus horikoshii. Process Biochem 38: 155-159.

47. Dorcas K, Dathar V \& Pindi PK (2016). Purification And Characterization Of Protease Produced By Bacillus cereus NC77. Inter J Pharm Bio Sci 7: 898 903.

48. Cui H, Wang L \& Yu Y (2015). Production and Characterization of Alkaline Protease from a High Yielding and Moderately Halophilic Strain of SD11 Marine Bacteria. J Chem 1-8.

49. Pillai P \& Archana G (2008). Hide depilation and feather disintegration studies with keratinolytic serine protease from a novel Bacillus subtilis Isolate. Appl Microbiol Biotechnol 78: 643-650.

50. El-Rafii HA, Naby A, MA, Gaballa A, AlAraby MH, Fateh AF (2005). Improvement of newly isolated Bacillus pumilus FH9 keratinolytic activity. Process Biochem 40: 2325-2332.

51. Fellahi S, Helmy MGAD, Zaghloul TI, Feuk-Lagerstedt E \& Taherzadeh M (2014). A Bacillus Strain Able to Hydrolyze Alpha- and Beta-Keratin. $J$ Bioprocess \& Biotech 4: 181.

52. Peddu J, Chitturi C \& Lakshmi V (2009). Purification and Characterization of Keratinase from Feather Degrading Bacillus sp. Inter J Microbiol 8: 1-9.

53. Cortezi M, Contiero J, Cristian JB, de Lima, Lovaglio RB \& Monti R (2008). Characterization of a Feather Degrading by Bacillus amyloliquefaciens Protease: A New Strain. World J Agric Sci 4: 648-656.

54. Mehta RS, Jholapara RJ \& Sawant CS (2014). Isolation of a novel featherdegrading bacterium and optimization of its cultural conditions for enzyme production. Int J Pharm Pharm Sci 6: 194201.

55. Sapna R \& Yamini V (2011).study of keratin degradation by some potential bacterial isolates from soil. J Soil Sci 1: 0103.

56. Arulmani M, Aparanjini K, Vasanthi K, Arumugam $\mathrm{P}$, Arivuchelvi $\mathrm{M} \&$ Kalaichelvan PT (2007). Purification and 
partial characterization of serine protease from thermostable alkalophilic Bacillus laterosporus-AK1. World J Microbiol Biotechnol 23: 475-481.

57. Oberoi R, Beg, Q. K., Puri, S., Saxena, R.K. \& Gupta, R. (2001). Characterization and wash performance analysis of an SDSstable alkaline protease from a Bacillus $s p$. World J Microbiol \& Biotechnol 17: 493497.

58. Rao CS, Sathish T, Ravichandra P \& Prakasham RS (2009).Characterization of thermo- and detergent stable serine protease from isolated Bacillus circulans and evaluation of eco-friendly applications. Process Biochem 44: 262 268.

59. Najafi MF \& Deobagkar D (2005). Potential application of protease isolated from Pseudomonas aeruginosa PD100. Elect J Biotechnol 8: 197-203.

60. Jayakumar R, Jayashree S, Annapurna B \& Seshadri S (2012).Characterization of Thermostable Serine Alkaline Protease from an Alkaliphilic Strain Bacillus pumilus MCAS8 and Its Applications. Biotechnol Appl Biochem 168: 18491866.

61. Niyonzima FN \& More SS (2015). Purification and characterization of detergent-compatible protease from Aspergillus terreusgr. Biotech 5: 61-70.

62. Vishalakshi N, Lingappa K, Amena S, Prabhakar M \& Dayanand A (2009). Production of alkaline protease from Streptomyces gulbargensis and its application in removal of blood stains. Indian J Biotechnol 8: 280-285.

63. Saminathan \& Narayanan (2015). Purification And Characterization Of Blood Stain Decolorizing Alkaline Metalloprotease From Bacillus Subtilis Ias 01 For Promising Bio-Detergent. Int J Recent Sci Res 6: 3010-3015.

64. Pathak AP \& Deshmukh KB (2012). Alkaline protease production, extraction and characterization from alkaliphilic Bacillus licheniformis KBDL4: A Lonar soda lake isolate. Indian J Exp Bio 50: 569-576.

65. Sivasubramanian S, Manohar BM, Rajaram A \& Puvanakrishna R (2008). Eco-friendly lime and sulfide free enzymatic dehairing of skins and hides using a bacterial alkaline protease. Chemosphere 70: 1015-1024.

66. Vijayaraghavan P, Lazarus S, Gnana S \& Vincent P (2014). De-hairing protease production by an isolated Bacillus cereus strain AT under solid-state fermentation using cow dung: Biosynthesis and properties. Saudi J Biol Sci 21: 27-34.

67. Abdel-Fattah AM (2013). Novel keratinase from marine Nocardiopsis dassonvillei NRC2aza exhibiting remarkable hide dehairing. Egyptian Pharm J 12: 142-147.

68. Uttangi V \& Aruna K (2018). Optimization of Production and Partial Characterization of Keratinase Produced by Bacillus thuringiensis strain Bt407 Isolated from Poultry Soil. Int J Curr Microbiol Appl Sci 7: 596-626.

69. Jaouadi NZ, Rekik H \& Badis A (2013). Biochemical and Molecular Characterization of a Serine Keratinase from Brevibacillus brevis US575 with Promising Keratin-Biodegradation and Hide-Dehairing Activities. PLoS One 8: $1-18$.

70. Zambare VP, Nilegaonkar SS \& Kanekar PP (2007). Production of an alkaline protease by Bacillus cereus MCM B-326 and its application as a dehairing agent. World J Microbiol Biotechnol 23: 15691574.

71. Lateef A, Adelere IA \& Gueguim-Kana EB (2015). Bacillus safensis LAU 13: A new source of keratinase and its multi-functional biocatalytic applications. Biotechnol Biotechnol Equip 29: 54-63.

72. Priyadarshini S, Gopinath V, Priyadharsshini NM, Ali DM \& Velusamy $P$ (2013). Synthesis of anisotropic silver nanoparticles using novel strain, Bacillus flexus and its biomedical application. Colloids Surf B 102: 232-237. 
73. Khan NT \& Jameel N (2016). Antifungal Activity of Silver Nanoparticles Produced from Fungus, Penicillium fellutanum at Different $\mathrm{pH}$. J Microbial \& Biochem Technol 8: 440-443.

74. Mukherjee P, Ahmad A, Mandal D, Senapati S \& Sainkar SR (2001). Fungusmediated synthesis of silver nanoparticles and their immobilization in mycelia matrix: A novel biological approach to nanoparticle synthesis. Nano Lett 1: 515519.

75. Thomas R, Janardhanan A, Varghese RT, Soniya EV, Mathew J \& Radhakrishnan EK (2014). Antibacterial properties of silver nanoparticles synthesized by marine Ochrobactrum Sp. Brazilian J Microbiol 45: 1221-1227.

76. Nithya G, Shepangam NH \& Balaji S (2011). Biosynthesis of silver nanoparticle and its antibacterial activity. Arch Appl Sci Res 3: 377-380.

77. Raffi M, Hussain F, Bhatti TM, Akhter JI, Hameed A \& Hasan MM (2008). Antibacterial Characterization of Silver Nanoparticles against E: Coli ATCC15224. J Mater Sci Technol 24: 192-196.

78. Sadhasivam S, Shanmugam P \& Yun K (2010) Biosynthesis of silver nanoparticles by Streptomyces hygrocopicus and antimicrobial activity against medically important pathogenic microorganisms. Colloids Surf B Biointerfaces 81: 358-362.

79. Lin YSE, Vidic RD, Stout JE, McCartney CA \& Yu VL (1998). Inactivation of Mycobacterium avium by copper and silver ions. Water Res 32:1997-2000.

80. Kalimuthu K, Babu RS, Venkataraman D, Bilal M \& Gurunathan S (2008). Biosynthesis of silver nanocrystals by Bacillus licheniformis. Colloids Surf B Biointerfaces 65: 150-153.
81. Saravanan M, Vemu AK \& Barik SK (2011). Rapid biosynthesis of silver nanoparticles from Bacillus megaterium (NCIM 2326) and their antibacterial activity on multi drug resistant clinical pathogens. Colloids Surf B 88: 325-331.

82. Elgorban AM, El-Samawaty AEM, Yassin MA, Sayed SR, Adil SF, Elhindi KM, Bakri M \& Khan M (2016) Antifungal silver nanoparticles: synthesis, characterization and biological evaluation. Biotechnol Biotechnol Equip 30: 56-62.

83. Alananbeh KM, Al-refaee WJ \& Al-qodah $Z$ (2017). Antifungal effect of silver nanoparticles on selected Fungi isolated from raw and waste water. Indian J pharm sci 79: 559-567.

84. Ahmed AS, Al-Domany RA, El-Shayeb NMA, Radwan HH \& Saleh SA (2008). Optimization, immobilization of extracellular alkaline protease and characterization of its enzymatic properties. Res J Agric Biol Sci 4: 434-446.

85. Masui A, Fujiwara N, Takagi M \& Imanaka T (1999). Feasibility study for decomposition of gelatin layers on X-ray films by thermostable alkaline protease from alkaliphilic Bacillus sp. Biotech Tech 13: 813-815.

86. Al-Abdalall AH \& Al-Khaldi EM (2016). Recovery of silver from used X-ray film using alkaline protease from Bacillus subtilis sub sp. subtilis. African $J$ Biotechnol 15: 1413-1416.

87. Fujiwara N, Tsumiya $\mathrm{T}$, Katada $\mathrm{T} \&$ Hosobuchi K (1989). Continuous recovery of silver from used X-ray films using a proteolytic enzyme. Process Biochem 24: 155-156. 